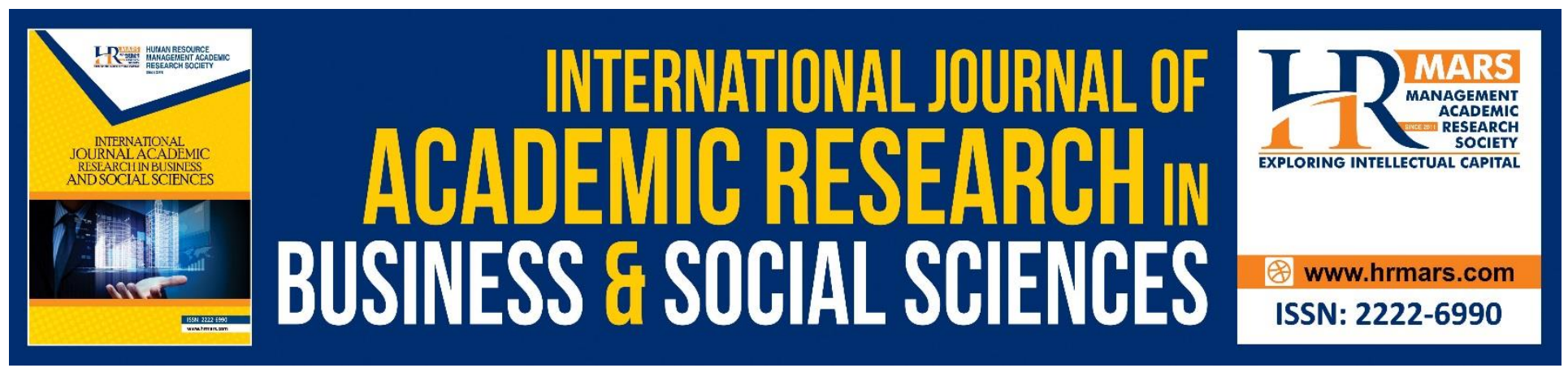

\title{
Building a Personality by Installing Noble Values: Implementing Nursi's Thoughts in a Malaysia Context
}

Mohamad Zaidin Mohamad, Kamarul Shukri Mat Teh, Sofyuddin Yusof, Ahmad Fauzi Hasan, Ahmad Zahid Salleh, Ahmad Bukhori Ghazali

To Link this Article: http://dx.doi.org/10.6007/IJARBSS/v8-i11/4914

DOI: $10.6007 /$ IJARBSS/v8-i11/4914

Received: 16 Oct 2018, Revised: 07 Nov 2018, Accepted: 19 Nov 2018

Published Online: 28 Nov 2018

In-Text Citation: (Mohamad et al., 2018)

To Cite this Article: Mohamad, M. Z., Teh, K. S. M., Yusof, S., Hasan, A. F., Salleh, A. Z., \& Ghazali, A. B. (2018). Building a Personality by Installing Noble Values: Implementing Nursi's Thoughts in a Malaysia Context. International Journal of Academic Research in Business and Social Sciences, 8(11), 437-444.

Copyright: (C) 2018 The Author(s)

Published by Human Resource Management Academic Research Society (www.hrmars.com)

This article is published under the Creative Commons Attribution (CC BY 4.0) license. Anyone may reproduce, distribute, translate and create derivative works of this article (for both commercial and non-commercial purposes), subject to full attribution to the original publication and authors. The full terms of this license may be seen

at: http://creativecommons.org/licences/by/4.0/legalcode

Vol. 8, No. 11, 2018, Pg. 437 - 444

http://hrmars.com/index.php/pages/detail/IJARBSS

JOURNAL HOMEPAGE

Full Terms \& Conditions of access and use can be found at http://hrmars.com/index.php/pages/detail/publication-ethics 


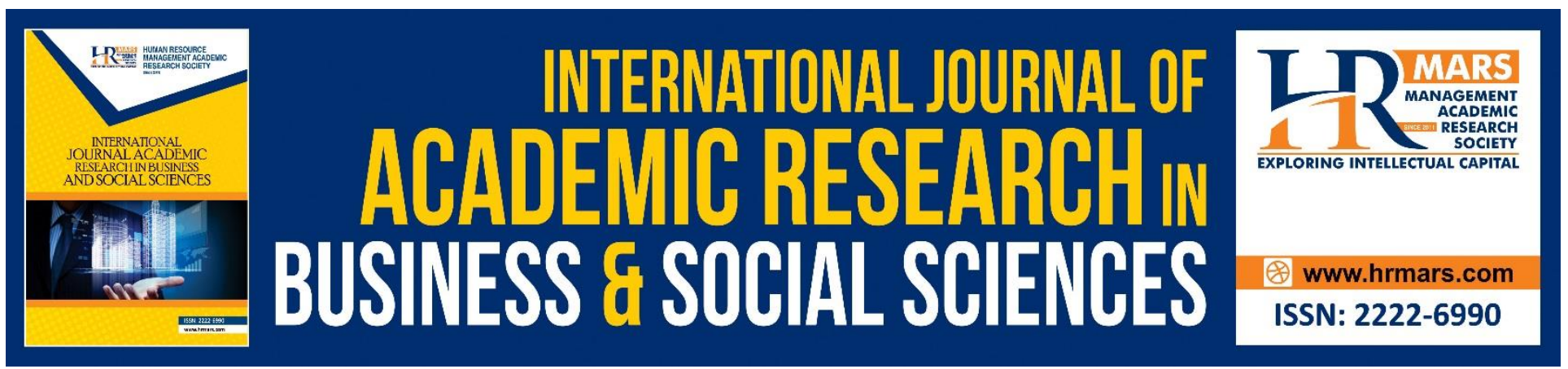

\title{
Building a Personality by Installing Noble Values: Implementing Nursi's Thoughts in a Malaysia Context
}

\author{
${ }^{1}$ Mohamad Zaidin Mohamad, ${ }^{1}$ Kamarul Shukri Mat Teh, ${ }^{1}$ Sofyuddin \\ Yusof, ${ }^{1}$ Ahmad Fauzi Hasan, ${ }^{1}$ Ahmad Zahid Salleh, ${ }^{2}$ Ahmad Bukhori \\ Ghazali \\ ${ }^{1}$ Universiti Sultan Zainal Abidin \\ ${ }^{2}$ Imtiyaz Travel and Tours \\ Corresponding Author: Mohamad Zaidin Mohamad.mzaidin@unisza.edu.my
}

\begin{abstract}
In facing a very challenging passage in time, Muslims need to possess a strong self-identity in order to progress together with the contemporary demands without sacrificing sacred religious values. Hence, this study aimed to explore Nursi's ideas related to the instilling of noble values as an element of self-identity. This qualitative study applied the content analysis method to achieve the objectives of the study. The findings showed that applying noble values is important in ensuring that the Islamic society continues to be relevant to its Islamic identity besides helping the country to maintain a level of inter-racial harmony. It also plays a role as an instrument for dakwah, especially for the non-Muslim community.
\end{abstract}

Keywords: Self-Identity, Noble Values, Inter-Racial Harmony, Multi-Racial Society, Islamophobia

\section{INTRODUCTION}

Generally, the Islamic society all over the world seriously views the question of Islamic personality after the emergence of the globalization era. This term has been frequently mentioned since the middle of the 1980s and became popular around the 1990s. According to al-'Ani (2009), two main factors that form the basis of this situation is the feeling of being threatened and the need to initiate reform. In the current situation, the need is based more on all the developments and changes in the world that include political, economic, social, technological and environmental aspects etc.

The global Islamic society, specifically in Malaysia, cannot be complacent but must participate with the global society in charting changes in their lives consistent with contemporary global developments. Therefore, every change or transformation that needs to be made must be Syariah compliant and not deviate from the sacred wants and guidelines of Islam. Here lies the importance of Islamic personality or identity. Without a strong personality, Muslims would be influenced by 
contemporary ideologies that are inconsistent with Islamic culture, civilised values or even history (Imarah, 2004).

\section{NURSI AND NOBLE VALUES}

Badiuzzaman Said Nursi (1877-1960) is a prominent figure in mujaddid (al-Hamid, 1995), who had a conceptual thought related to the self-identity of Muslims that needs further study. This is in view of his rather long lifetime that coincided with the identity crises of Muslims, specifically the Dawlah Uthmaniyyah. Thus, with the various inversed isms, such as materialistic, individualistic, secularistic, atheism and nationalist, besides the weak religious beliefs and hostile attitudes among themselves, it has left the self-identity of Muslims at a critical juncture.

Cultivating noble values means efforts to build unity according to the principle "accepting what is good and discarding what is unwanted". What is meant by "accepting what is good" is to appreciate good moral values, while "discard what is unwanted" is to discard inappropriate moral values. In al-Maktubat, Nursi supported unity between Muslims and non-Muslims centred on the appreciation of noble moral values. Nursi imagined an Islamic society with noble moral values as 'mu'min Muslim'. The non-Islamic society with noble moral values is referred to as 'Muslims without a religion' (muslim bila al-din).

The meeting point between 'mu'min Muslim' and 'Muslims without a religion' is the appreciation of morality (al-Nursi, 1992; Mohamad, 2017). This principle has some truth because Islam and all the other religions advocate good moral values. Although there exist differences in good and bad moral values philosophically and conceptually from the perspective of various religions, however, in general all religions place importance on appreciating noble moral values and encouraging its followers to propagate goodness among all parties (Charles, 1994).

This shows that noble values or universal values should be the catalyst in efforts to form comradeship or fellowship and cooperation. These noble values are able to strengthen relationships amongst Muslims and between Muslims and non-Muslims. Nursi understood the reality of the different faiths, which is the sunnatullah that cannot become an excuse for not extending mutual help in matters of goodness and bringing about benefits to all parties. Hence, based on Nursi's thoughts, the instrument of dialog needs to focus on instilling noble values (al-Nursi, 1999; Mohamad et al., 2014a).

\section{THE CHALLENGE OF INSTILLING NOBLE VALUES IN MALAYSIA}

The government understands the need for instilling harmony and unity among the people through the instilling of noble values that exist in every religion (Zakaria, 2001). Policies regarding the application of Islamic values and the Islam Hadhari approach (Ramli, 2009) are two examples of the government's efforts to create a society that is noble in nature. The Gagasan 1Malaysia, which is a combination of the government's earlier approaches, has also instilled noble values as a precondition for its success.

There are several noble values in Gagasan 1Malaysia that emphasises support for unity. Among some of these values are: 
a. Mutual Respect: Mutual respect between all races, including the respect for customs and culture of other races. This feeling of mutual respect also demands that we do not use profanity towards other races or question the legal provisions that touch on the sensitivities of races.

b. Humility: The feeling of humility is a feeling of awareness that Malaysians live together in harmony. It also means that each race or individual has weaknesses and strengths, hence, they should take advantage of their strengths to consolidate the society and nation.

c. Moderation: Moderation means taking a moderate approach in any issue that arises. In a multi-racial society like Malaysia, actions or words deemed extreme cannot be accepted because it could lead to serious problems associated with social instability.

d. Politeness: Politeness refers to words spoken and courteous behaviour that centres on being well-mannered in all interactions and relationships with other parties in order to generate stronger cooperation and consensus.

Hence, it could be summarised that instilling noble values is an approach that has been prioritised by the government for some time now. Nevertheless, the scenario depicting unity in Malaysia currently proves that this approach has not achieved its objective (Rahimin et al., 2011).

The author sees two reasons that pose the main challenges in realising the effective instilling of noble values. First, the absence of a model for society to evaluate and second, the apprehension by the non-Islamic society about the approach that is seen solely to recruit or attract them to Islam.

\section{SUGGESTIONS}

In order to overcome these challenges, it is suggested that:

a. The country's leadership, especially the ministers, need to show a good example to society by appreciating noble values in their lives. Leaders involved in social problems, corruption, abuse of power, cronyism, lavishness etc. are hindrances to instilling noble values lauded by the government. These issues would make some parts of society think that the government is not sincere in the policy on noble values or in other words, 'not walking the talk'. Thus, if those who should appreciate government policies are not doing so, how would one expect the general society to appreciate it. Briefly, the actions and behaviour of the nation's leadership would always be evaluated by the people. Hence, the slogan 'example through leadership' must be proved beyond doubt by the nation's leadership.

b. Suspicion by the non-Islamic community towards policies related to the application of Islamic values is an effort to consolidate the position of the Malay community and a characteristic of extreme Malay nationalism that threatens the position of the non-Islamic community (Jaffary, 2003). This suspicion can be overcome by propagating noble values that also exists in the nonIslam community. As long as these values are not contrary to Islamic teachings, Islam does not object to it. The notion that propagation of noble values of other cultures could threaten the position and sanctity of Islam is a misconception. This is because Islam believes in one clear 
INTERNATIONAL JOURNAL OF ACADEMIC RESEARCH IN BUSINESS AND SOCIAL SCIENCES

Vol. 8, No. 11, Nov, 2018, E-ISSN: 2222-6990 @ 2018 HRMARS

principle that does not stop its followers from adopting or duplicating any form of goodwill from another party.

The Prophet PBUH (Majah, n.d.) exhorted:

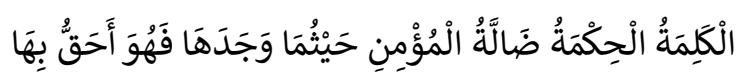

Meaning:

Words of wisdom (truth) are the property of a lost mukmin, where ever he finds it; hence, he deserves greater rights to that property

This matter is not something new because Malaysians have been introduced to the Look East Policy. Moreover, today, the government has adopted Culture 55, which is a part of Japanese work culture, and implemented it in government departments in order to improve current work practices (Anon, 2012, Guideline for 5S Practices - JPA, www.jpa.gov/docs/penerbitan). Hence, there is nothing wrong in introducing a certain policy from a culture belonging to a non-Islamic society to this country, such as the work culture of ethnic Chinese, environmentally friendly culture of the ethnic people etc. These policies act as a support for the government's current Islamization policies. In this way, the non-Islamic community can witness how their culture is appreciated by others. Besides that, the Islamic community itself could improve its understanding of other ethnic cultures, who are also Malaysian citizens like themselves.

\section{ENCULTURATING CONSCIENTIOUS REPROOFING}

Different forms of conscientious and moderate reproofing should be applied amongst the Malaysian society, specifically when addressing discord and misunderstandings among Malaysians. Unfortunately, in the Malaysian Muslim community, reproofing in the form of attacks and bashing are predominant. When 'attacks' are the main approach, it does not consider the confines of religion or the dignity of a person. The reproofing is not intended for correcting the situation anymore, instead its motive is more towards discrediting and demeaning a person. Consequently, the reproofing is not only rejected wholly but aggravates the situations, it is countered with personal attacks. The situation in this country portrays the reminder from Nursi, "violence can only be replied with violence" (al-Nursi, 1995). Eventually, the country's stability and harmony are jeopardised. It is not surprising that the principle of moderation becomes the focus of discussion by leaders and citizens of this country. This reality can be seen in Gagasan 1Malaysia, which emphasises on the aspect of moderation (Petah, 2011).

Moreover, the former King, HH Tuanku Mizan Zainal Abidin also sent a reminder about the demand for moderation when officiating the National Level Maal Hijrah 2011, whose theme was 'The Basic Understanding of Unity Among the Ummah' held at the Putrajaya International Convention Centre (PICC), on 27 November 2011 (Utusan Malaysia, 2011).

Briefly, the negative phenomenon arising from a non-conscientious reproofing leads to several undesirable consequences, such as increasing the misunderstanding gap between Malays and exposing confidential personal information so much so that spying and trespassing on someone's 
privacy is not presumed to be against Islamic teachings. Consequently, there arises numerous words that were taboo at one time, prohibited and not heard of as well as used or a non-existent term in Malay. For example, the word sodomy, homosexual (gay and lesbian), maknyah (transvestite) etc., that have been used extensively in the newspapers, popular entertainment magazines and the Internet (Baharuddin, 2007). Indirectly, this unhealthy phenomenon invites a negative impact to the sociology of the Malay community and also the perception of non-Muslims towards the sanctity of Islam.

Unconscientious reproofing has formed a non-objective thinking in the minds of society, especially among the groups that are in conflict. This leads to a scenario of blind rejection before investigating the truth and virtues of a matter at hand. The current scenario that occurred during a Cabinet meeting could explain this matter. A part of the Cabinet meeting, which is presumed to be a 'noble' place for discussing matters of benefit to the country and society, was no longer respected. The Chambers has changed into a place for personal attacks against a person, letting lose anger, verbal wars etc., thus, portraying behaviour unbecoming of those referred to as 'Yang Berhormat' (Your Honourable). However, if this negative and disgraceful phenomenon is not curtailed, it is not impossible that a circus-like Parliament sitting, like the one in Taiwan, could occur in Malaysia. This situation could jeopardise society's confidence towards the credibility of these leaders and dilute their respect regarding the nobility of Parliament.

Among the reasons for this problem is the fanatical attitude in oneself or their own group. In order to overcome this plague, Nursi's approach should be given some attention. He said that, "my way in the best", but he should not say, "only my way is good and the only way" (al-Nursi, 1992; Mohamad et al., 2014b) and this must be appreciated by the Malay society today. Besides that, the idea or concept "if you do not like something, make a better one", is suitable for propagating the value of tolerance in social relations, giving value to each view as well as not haphazardly criticising or protesting against other parties. This is because there are no humans or any group that is perfect and free from weaknesses or mistakes. Hence, fanaticism should be avoided at all costs because it is against sincerity and also good virtues. Nursi (1999) reminded us that:

"Among the deceptions of egoism is that one feels he is right and those who differ in their views are wrong. Thus, disputes and unhealthy competition will replace unity and love. At the same time, sincerity is lost as well as practices and its positive effects (expected) dissipate and become too difficult to achieve"

Besides that, criticisms in the form insults or name-calling are also against the principles of conscientious reproofing. This phenomenon is evident among the Malaysian society. One example is the issue regarding 'Mat Indera'. The author finds no problems in striking a dialog and discussing issues about the country's history because it could glorify scholarly values and openness, either among academicians or the community at large. The evaluation and writing of history is not absolute or resistant to accepting views and new arguments because historical facts are exposed to different interpretations and consensus. What should be certain is a calm and ethical atmosphere when debating these issues. The pros and cons of Mat Indera's struggle portrays a variety of views and differences that emerge from various dimensions of historical facts that are examined and assessed 
by a person. Hence, problems and conflict among the society are due to entities that give strong views, which eventually cause the chagrin of other parties. Shameful and distasteful name-callings such as 'Communist supporter', 'colonizer's bootlicker', 'colonizer's hunting dog' etc. should not happen in a civilised society such as in this country.

Nursi strongly emphasised the etiquette of reproofing and advising. Among the etiquettes practiced by Nursi was that he did not mention the figure he was reproofing. Conversely, reproofing and corrections were focused on erred views through constructive criticisms as well as based on knowledge and the truth. The method used by him was to "make a lesson of the thoughts, not the individual" and "you will not know the truth by looking at someone but rather, firstly know the truth then you will know the true person" (al-Karami, 1406H). He never called names on anyone, what more if the reproof was related to an academic figure (al-Nursi, 1998). A reproof that was not in a conscientious manner only added defiance and rejection besides giving rise to misunderstanding and altercations among the society. This kind of attitude is strongly forbidden and warned by the Prophet $\mathrm{PBUH}$ in a hadith (al-Bukhari, n.d.).

Meaning:

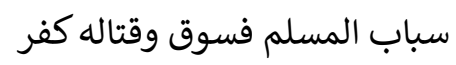

To scorn a Muslim is fasik (impious) and to kill him is kufur (blasphemous)

Briefly, reproofing in a conscientious manner has not become a culture among the Malay society. Whereas, this value has an immense influence in forming a society that practices mutual respect and cooperation in anything good.

\section{CONCLUSION}

Touching on the question of instilling noble values among society, it is beyond doubt that it is a good step towards building a Malaysian race that is united and practices mutually cooperation for the betterment of the nation. Numerous values can be promoted and become a catalyst for enhancing the spirit of national unity, such as the practice of reproofing any person(s) in a conscientious manner because 'to err is human'. Hence, the noble value element, as emphasised by Nursi's thoughts, should be accepted, expanded and implemented amongst the multi-racial society of Malaysia

\section{ACKNOWLEDGEMENT}

Special thanks to Research Management, Innovation \& Commercialization Centre (RMIC) and University Sultan Zainal Abidin (UniSZA) for funding this research (R0034-R026).

\section{REFERENCES}

Al-'Ani. (2009). al-Huwiyyah al-Islamiyyah fi Zaman al- 'Awlamah al-Thaqafiyyah. Iraq: Markaz alBuhuth wa al-Dirasat al-Islamiyyah.

Anon. (2012), Panduan amalan 5s - JPA, www.jpa.gov/docs/penerbitan [2 April]. Baharuddin, S.A. (2007). Budaya Yang Tercabar. Kuala Lumpur: Dewan Bahasa dan Pustaka.

Al-Bukhari. n.d. al-Sahih. Istanbul: al-Maktabah al-Islamiyyah.

Charles, H.R.H. The Prince of Wales. (1994). Islam and the West, Arab Law Quarterly. 9(2): 135-143. 
Al-Hamid, M.A. (1995). al-Nursi Mutakallim al-Asr al-Hadith. Istanbul: Sozler, Istanbul.

Imarah, M. (2004). Ayyuhuma Awla: al-Huwiyyah am al-Nahdah. Jaridah al-Sharq al-Awsat. [22 Januari].

Jaffary, A. (2003). Toleransi agama dan perpaduan kaum: Respons intelek Malaysia - Satu observasi ringkas. In Jaffary Awang (ed.), Agama dan Perpaduan Kaum di Malaysia. Bangi: Universiti Kebangsaan Malaysia.

Al-Karami, M.Y. (1406H). Aqawil al-Thiqat fi Ta'wil al-Asma' wa al-Sifat wa al-Ayat al-Muhkamat wa al-Mushtabihat. Shu'ayb al-Arna'ut (ed.). Bayrut: Mu'assasat al-Risalah.

Majah, I. n.d. al-Sunan. Muhammad Fu'ad Abd al-Baqi (ed.). al-Qahirah: Dar al-Bayan li al-Turath.

Mohamad, M.Z., Yusof, K., Sulaiman, A.A., Ismail, D., Omar, L., Ismail, M.Z., Abdullah, W.I.W., Yaacob, A., Omar, M.C. \& Bakar, M.A. (2014a). Nursi's unity model and its importance in the context of racial unity in Malaysia. Mediterranean Journal of Social Sciences. 5(29): 87-92.

Mohamad, M.Z., Gulerce, H., M.S.I Zprulkahn, Chik, W.M.Y.W., Salleh, A.W., Yusof, S., Idris, M.F.H., Mohd, Z., Ismail, Affendi \& Yusof, K. (2014b). The value of moderation in the context of national unity in Malaysia. The Social Sciences. 9(6): 402-407.

Mohamad, M.Z., Omar S.H.S., Ismail, M.Z., Yusof, S. \& Laki, A.F. (2017). The Disseminationof Dakwah through the Instrument of Civilizational Dialogue and Wasatiyyah according to Nursi's Thought. International Journal of Academic Research in Business and Social Sciences. 7(10): 341-346.

Al-Nursi, B.Z.S. (1992). al-Maktubat. Ihsan Qasim al-Salihi (trans.). Istanbul: Sharikat al-Nasl li alTiba`ah.

Al-Nursi, , B.Z.S. (1995). Sayqal al-Islam. Ihsan Qasim al-Salihi (trans.). Istanbul: Sharikat al-Nasl li alTiba`ah.

Al-Nursi, , B.Z.S. (1998). Sirah Dhatiyyah. Ihsan Qasim al-Salihi (trans.). Istanbul: Matba'at Suzlar.

Al-Nursi, , B.Z.S. (1999). al-Lam `at. Terj. Ihsan Qasim al-Salihi. Istanbul: Matba'at Suzlar.

Petah, M. 2011. Falsafah Gagasan 1Malaysia. Selangor: Amnas Enterprise.

Rahimin, A.A.R., Ramli, M.A., Ismail, P. \& Dahlal, N.H.M. (2011). Dialog antara agama; realiti dan prospek di Malaysia. Kajian Malaysia. 29(2): 91-110.

Ramli, A.H. (2009). Hubungan Kaum di Malaysia: Sejarah dan Asas Perpaduan. Selangor: Pusat Penerbitan Universiti.

Utusan Malaysia. (2011). 28 November.

Zakaria, I. (2001). Malaysia dan masalah perpaduan kaum. Pemikir. Julai-September: 91-112. 